\title{
Control of Valine and Isoleucine Metabolism in Pseudomonas aeruginosa and Escherichia coli
}

\author{
By I. HORVÁTH, J. M. VARGA ANd A. SZENTIRMAI \\ Department of Microbiology, Research Institute of the \\ Pharmaceutical Industry, Budapest, Hungary
}

(Received 2 July 1963)

\begin{abstract}
SUMMARY
Isoleucine increased the quantity of $\alpha$-acetolactic acid-forming enzyme which takes part in the synthesis of valine and isoleucine in Pseudomonas aeruginosa. Threonine and $\alpha$-ketobutyric acid, the precursors of isoleucine, had a similar effect. In $P$. aeruginosa during the initial stage of growth after inoculation, a temporary substantial increase of $\alpha$-acetolactic acidforming enzyme can be observed. This increase was not so great when valine was present, and was enhanced by isoleucine, which was effective during the whole period of growth. The repressive effect of valine can be counteracted with isoleucine and the end product inductive effect of isoleucine can be inhibited by valine. In extracts of disrupted organisms the activity of the $\alpha, \beta$-dihydroxy acid dehydrase changes parallel with the concentration of the $\alpha$-acetolactic acid-forming enzyme.

In the case of Escherichia coli the repressive effect of valine on the $\alpha$-acetolactic acid-forming enzyme can be counteracted with isoleucine.
\end{abstract}

\section{INTRODUCTION}

It was shown by Umbarger \& Brown (1958a) for Escherichia coli, and then by Halpern \& Umbarger (1959) for Aerobacter aerogenes, that the quantity of $\alpha$-acetolactic acid-forming enzyme which took part in the biosynthesis of valine and isoleucine substantially increased during the initial period of growth, and that this increase was repressed by valine. Radhakrishnan \& Snell (1960) found no similar effect in the case of Neurospora crassa. Horváth, Gadó \& Szentirmai (1961, 1962) found that in Streptomyces rimosus $\alpha$-ketobutyric acid inductively increased the quantity of this enzyme. Freundlich, Burns \& Umbarger (1962), investigated in auxotroph mutants of Salmonella typhimurium the effect of the products upon the quantity of enzymes taking part in the synthesis of valine and isoleucine, and showed that there existed some correlation in the regulation of these processes. In the present experiments the regulation of metabolic processes was investigated in Pseudomonas aeruginosa and E. coli.

\section{METHODS}

Organisms. The experiments were carried out with Pseudomonas aeruginosa, laboratory strain No. 132, and Escherichia coli strain $\mathrm{K} 12$.

Cultivation. In the experiments Erlenmeyer flasks $(500 \mathrm{ml}$.) each containing $200 \mathrm{ml}$. of medium were incubated in the case of Pseudomonas aeruginosa at $28^{\circ}$ and in the case of Escherichia coli at $37^{\circ}$ on reciprocal shakers (diameter $2 \mathrm{~cm}$., rev./min. 300). 
Media and inoculation. Pseudomonas aeruginosa was cultivated on media containing $(\%, w / v)$ : L-glutamic acid, 0.5 (neutralized with sodium hydroxide); $\mathrm{MgSO}_{4} .7 \mathrm{H}_{2} \mathrm{O}, 0.05 ; \mathrm{K}_{2} \mathrm{HPO}_{4}, 0.7 ; \mathrm{KH}_{2} \mathrm{PO}_{4}, 0.3$; glucose, 0.4 . The phosphates and glucose were sterilized separately. The other components of the nutrient medium, and their concentrations, are listed in the tables and figures. Inoculation was as follows: $200 \mathrm{ml}$. of medium was inoculated with a $24 \mathrm{hr}$ broth culture. After $24 \mathrm{hr}$ a sample, $1 \mathrm{ml}$. or $5 \mathrm{ml}$. depending on the experiment, was taken for inoculation of the experimental media.

Escherichia coli was cultivated on a minimal medium described by Davis \& Mingioli (1950), from which citrate was omitted (Umbarger \& Brown, 1958a). The additions to the medium are shown in the tables. The bacteria were grown at least three times in minimal medium before the actual experiments. The inoculation was carried out with $10 \mathrm{ml}$. portions of a $16 \mathrm{hr}$ culture. Samples were taken at $0 \mathrm{hr}$ and the $3 \mathrm{rd} \mathrm{hr}$, when the increase of enzyme activity following inoculation was at its peak.

Enzyme methods. The determination of $\alpha$-acetolactic acid-forming enzyme in toluene-treated organisms was done by the method, slightly modified, of Halpern \& Umbarger (1959). Two ml. of the reaction mixture contained 0.4-0.5 mg. dry wt. washed organisms, $50 \mu$ mole magnesium chloride, $100 \mu$ mole potassium phosphate (pH 8.0), $100 \mu \mathrm{g}$. thiamine pyrophosphate (TPP), and $0.02 \mathrm{ml}$. toluene. After incubation for 30 min. at $28^{\circ}, 25 \mu$ mole sodium pyruvate in $0.5 \mathrm{ml}$. were added.

$\mathrm{N}$-Sodium hydroxide (0.25 $\mathrm{ml}$.), N-zinc sulphate $(0.25 \mathrm{ml}$.) were added to stop the reaction. Immediately after this $\alpha$-acetolactic acid was determined in a sample, according to Westerfeld (1945), as acetoin after decarboxylation with $\mathrm{N}$-sulphuric acid.

The determination of $\alpha$-acetolactic acid forming enzyme in crude extracts was done by the method, slightly modified, of Umbarger \& Brown (1958b). The composition of the reaction mixture was as follows: 0.5 mmole potassium phosphate $\mathrm{pH} 8 \cdot 0$, $50 \mu$ mole sodium pyruvate, $100 \mu \mathrm{g}$. TPP, $10 \mu$ mole magnesium sulphate and $4-5 \mathrm{mg}$. protein; total volume $1 \mathrm{ml}$. The reaction mixture was incubated at $37^{\circ}$ for $10 \mathrm{~min}$., the reaction was stopped by adding $1 \cdot 8 \mathrm{~N}$-sulphuric acid and the $\alpha$-acetolactic acid determined as acetoin after decarboxylation.

The method of Wixom, Shatton \& Strassman (1960) was used for determining the $\alpha, \beta$-dihydroxyacid dehydrase activity with $\mathrm{DL}-\alpha, \beta$-dihydroxyisovaleric acid or $\mathrm{DL}-\alpha, \beta$-dihydroxymethylvaleric acid as substrates. The resulting keto acids were determined by the method of Cavallini \& Frontali (1954), as modified by Strassmann, Shatton \& Weinhouse (1960).

Disruption of organisms. After harvesting and washing with buffer the cell paste was suspended in $0 \cdot 1 \mathrm{M}$-potassium phosphate ( $\mathrm{pH} \mathrm{8 \cdot 0)}$ ). The suspensions (50 mg. dry wt./ml.) were disrupted by a $12 \mathrm{~min}$. treatment in a MSE Mullard ultrasonic apparatus, at $0-2^{\circ}$, and then centrifuged at $20,000 \mathrm{~g}$ for $15 \mathrm{~min}$. in a refrigerated centrifuge. The clear supernatant fluid was used immediately for enzyme determination. The protein content of the crude extract varied between 20 and $25 \mathrm{mg}$. $/ \mathrm{ml}$. Protein was determined by the method of Lowry, Rosebrough, Farr \& Randall (1951).

Chemicals. DL- $\alpha, \beta$-Dihydroxy-isovaleric and $\mathrm{DL}-\alpha, \beta$-dihydroxy- $\beta$-methylvaleric acid were synthesized according to Sjolander, Folkers, Adelberg \& Tatum (1954); $\alpha$-keto-isovaleric and $\alpha$-keto- $\beta$-methylvaleric acids were prepared from valine and 
isoleucine, respectively, with amino acid oxidase, by the method of Meister \& Tice (1950).

The other substances were of analytical reagent or purissimum grade.

\section{RESULTS}

Induction of the $\alpha$-acetolactic acid-forming enzyme with isoleucine. In the first series of experiments the amount of the $\alpha$-acetolactic acid-forming enzyme was determined in $14 \mathrm{hr}$ cultures from $1 \%(\mathrm{v} / \mathrm{v})$ inocula. Results are summarized in Table 1. When different quantities of isoleucine were added to the medium, a gradual increase in the enzyme level up to fourfold at the highest concentration could be observed. Valine did not affect the production of enzyme, but it decreased the inductive effect of isoleucine. No stoichiometric relationship between valine and isoleucine was found in connexion with their antagonistic effect. Isoleucine precursors, e.g. threonine, $\alpha$-ketobutyric acid, also had an inductive effect and this effect was decreased by valine; in similar concentrations, other natural amino acids had no effect. The different substances added to the medium did not affect the growth of the organisms. The inductive effect of isoleucine was observed with several strains of Pseudomonas aeruginosa.

Table 1. The effect of the composition of the medium upon the $\alpha$-acetolactic acidforming enzyme level in cells of Pseudomonas aeruginosa

$\mu$ mole
$\alpha$-acetolactic
acid/mg.
bacteria dry
wt./hr
$0 \cdot 38$
$0 \cdot 96$
$1 \cdot 56$
$1 \cdot 60$
$0 \cdot 42$
$1 \cdot 61$
$0 \cdot 43$
$1 \cdot 74$
$0 \cdot 40$
$1 \cdot 22$
$0 \cdot 56$
1.55
$0 \cdot 55$

Variation in amount of the $\alpha$-acetolactic acid-forming enzyme during incubation. When $5 \mathrm{ml}$. portions of the inoculum were used the $\alpha$-acetolactic acid-forming enzyme value paralleled the growth rate of Pseudomonas aeruginosa and a more intensive synthesis of enzyme was noted during the initial period of growth (Fig. 1). When isoleucine was added to the medium the initial increase of the enzyme value became substantially higher and, during the whole period of growth, the enzyme value of the organisms was much higher than in organisms grown on minimal medium. Valine repressed this enhanced synthesis of enzyme. When valine+isoleucine were added to the medium in similar concentrations the change in enzyme value was identical with that observed in organisms grown on minimal medium; i.e. valine and isoleucine neutralized the effect of each other. Investigations were 
carried out to determine the greatest time after inoculation at which the addition of end products still produced an effect. It was observed that additions $1 \mathrm{hr}$ after inoculation from the beginning of the log phase were still effective, but beyond that time neither a repressive effect of valine, nor an inductive effect of isoleucine, was observed.

The parallel change of the amount of $\alpha$-acetolactic acid-forming enzyme with that of $\alpha, \beta$-dihydroxyacid dehydrase. For the further support of the experimental findings mentioned, the activity in cell-free extracts of the $\alpha$-acetolactic acid-forming enzyme and of the $\alpha, \beta$-dihydroxyacid dehydrase taking part in the biosynthesis of

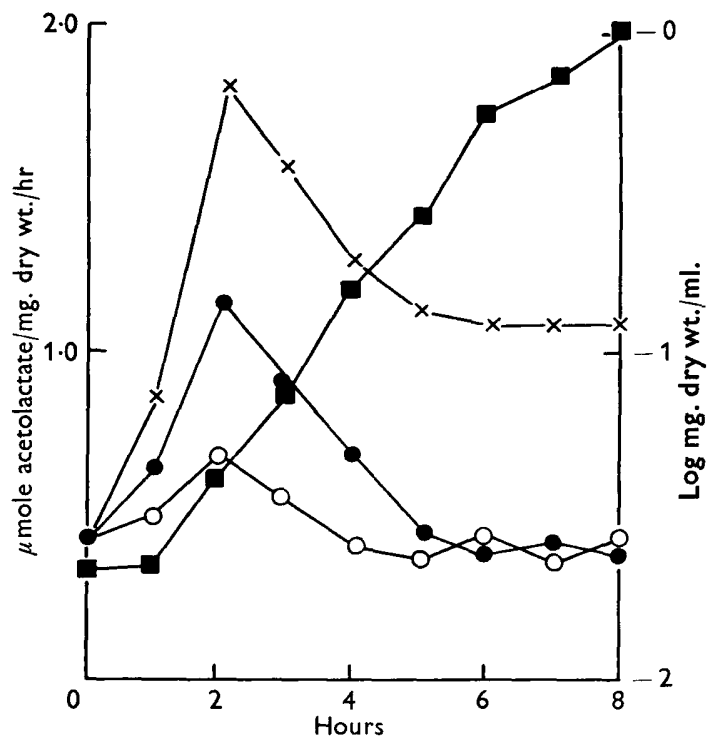

Fig. 1. The effect of the composition of the minimal medium upon the change of the $\alpha$-acetolactic acid-forming enzyme activity of the cells of Pseudomonas aeruginosa. - - Minimal medium; $\mathrm{O}-\mathrm{O}$, minimal medium $+600 \mu \mathrm{g} . / \mathrm{ml}$. DL-valine; $\times-\times$, minimal medium $+900 \mu \mathrm{g} . / \mathrm{ml}$. DL-isoleucine; $\square-\square$, growth.

valine and isoleucine was determined. After the disruption of organisms of different ages and grown on different media, it was found (Table 2) that the activity of the $\alpha$-acetolactic acid-forming enzyme and that of the $\alpha, \beta$-dihydroxyacid dehydrase changed correspondingly.

The inhibition of $\alpha$-acetolactic acid-forming enzyme with valine. Umbarger \& Brown (1958b) and Halpern \& Umbarger (1959) showed that the $\alpha$-acetolactic acid-forming enzyme taking part in the biosynthesis of valine and isoleucine is competitively inhibited by valine in Escherichia coli and Aerobacter aerogenes. The enzyme in Pseudomonas aeruginosa can be similarly inhibited by valine (Table 3 ).

The effect of isoleucine on valine repression of the $\alpha$-acetolactic acid-forming enzyme in Escherichia coli. It is known that valine has a repressive effect on the synthesis of $\alpha$-acetolactic acid-forming enzyme, but the antagonistic effects of valine and isoleucine observed in Pseudomonas aeruginosa have not been unequivocally demonstrated in the case of $E$. coli. We found, in accordance with the 
Table 2. The activity of $\alpha$-acetolactic acid-forming enzyme, and $\alpha, \beta$-dihydroxyacid dehydrase in cell-free extracts of Pseudomonas aeruginosa

\begin{tabular}{|c|c|c|c|c|c|c|c|}
\hline \multirow[b]{2}{*}{$\begin{array}{l}\text { Age of culture } \\
\text { Medium }\end{array}$} & \multirow[b]{2}{*}{$\cdots$} & \multicolumn{2}{|c|}{$\begin{array}{c}\mu \text { mole acetolactic } \\
\text { acid } / \mathbf{m g} . \\
\text { protein } / \mathbf{h r}\end{array}$} & \multicolumn{2}{|c|}{$\begin{array}{c}\mu \text { mole } \alpha \text {-ketoisolvaleric } \\
\text { acid } / \mathrm{mg} . \\
\text { protein } / \mathrm{hr}\end{array}$} & \multicolumn{2}{|c|}{$\begin{array}{c}\mu \text { mole } \alpha \text {-keto- } \beta \text {-methyl } \\
\text { valeric acid } / \mathrm{mg} . \\
\text { protein } / \mathrm{hr}\end{array}$} \\
\hline & & $2 \mathrm{hr}$ & $8 \mathrm{hr}$ & $2 \mathrm{hr}$ & $8 \mathrm{hr}$ & $2 \mathrm{hr}$ & $8 \mathrm{hr}$ \\
\hline Minimal & & $2 \cdot 6$ & $1 \cdot 0$ & $\mathbf{3 \cdot 3}$ & $1 \cdot 5$ & $2 \cdot 8$ & $1 \cdot 1$ \\
\hline $\begin{array}{l}\text { Minimal }+900 \mu \mathrm{g} . / \mathrm{ml} \text {. } \\
\text { isoleucine }\end{array}$ & & $5 \cdot 0$ & $2 \cdot 5$ & $6 \cdot 4$ & $\mathbf{2} \cdot 8$ & $6 \cdot 4$ & $3 \cdot 2$ \\
\hline $\begin{array}{l}\text { Minimal }+600 \mu \mathrm{g} . / \mathrm{ml} . \\
\text { valine }\end{array}$ & & $1 \cdot 8$ & $1 \cdot 0$ & $\mathbf{2} \cdot \mathbf{0}$ & $1 \cdot 6$ & $1 \cdot 8$ & $1 \cdot 4$ \\
\hline
\end{tabular}

Table 3. The effect of valine on the $\alpha$-acetolactic acid-forming enzyme in cell-free extracts of Pseudomonas aeruginosa

$\begin{array}{ccc}\begin{array}{c}\text { DL-Valine } \\ \text { concentration } \\ (\mu \text { mole } / \text { ml. })\end{array} & \begin{array}{c}\text { Acetolactic } \\ \text { acid formed } \\ (\mu \text { mole } / \text { mg. } \\ \text { protein } / \text { hr })\end{array} & \begin{array}{c}\text { Inhibition } \\ (\%)\end{array} \\ 0.00 & 6 \cdot 20 & \\ 0.05 & 3 \cdot 86 & 0 \\ 0 \cdot 10 & 2 \cdot 46 & 38 \\ 0.50 & 1 \cdot 19 & 60 \\ & & 81\end{array}$

Table 4. $\alpha$-Acetolactic acid-forming enzyme in Escherichia coli strain $\mathrm{k} 12$

\begin{tabular}{|c|c|c|c|}
\hline Medium & $\begin{array}{r}\text { Time } \\
\text { (hr) }\end{array}$ & $\begin{array}{c}\text { Opt. } \\
\text { density at } \\
650 \mathrm{~m} \mu \text {. }\end{array}$ & $\begin{array}{c}\alpha \text {-Acetolactic } \\
\text { acid formed } \\
\text { ( } \mu \text { mole/mg. } \\
\text { dry wt./hr) }\end{array}$ \\
\hline Minimal & $\mathbf{0}$ & 42 & $0 \cdot 12$ \\
\hline Minimal & $\mathbf{3}$ & 150 & 0.54 \\
\hline Minimal $+25 \mu \mathrm{g} . / \mathrm{ml}$. DL-valine & 3 & 70 & $0 \cdot 29$ \\
\hline Minimal $+50 \mu \mathrm{g} . / \mathrm{ml}$. DL-valine & $\mathbf{8}$ & 65 & 0.23 \\
\hline Minimal $+50 \mu \mathrm{g} . / \mathrm{ml}$. DL-isoleucine & 3 & 148 & 0.50 \\
\hline $\begin{array}{l}\text { Minimal }+25 \mu \mathrm{g} . / \mathrm{ml} \text {. DL-valine }+ \\
25 \mu \mathrm{g} . / \mathrm{ml} \text {. DL-isoleucine }\end{array}$ & 3 & 150 & 0.75 \\
\hline $\begin{array}{l}\text { Minimal }+25 \mu \mathrm{g} . / \mathrm{ml} \text {. DL-valine }+ \\
50 \mu \mathrm{g} . / \mathrm{ml} . \text { DL-isoleucine }\end{array}$ & $\mathbf{3}$ & 150 & 0.79 \\
\hline
\end{tabular}

Table 5. Inhibition of $\alpha$-acetolactic acid-forming enzyme with DL-valine in case of Escherichia coli strain $\mathrm{k} 12$

\begin{tabular}{|c|c|c|c|}
\hline & \multicolumn{3}{|c|}{$\begin{array}{l}\alpha \text {-Acetolactic acid formed } \\
(\mu \mathrm{mole} / \mathrm{mg} . \mathrm{dry} \text { wt. } / \mathrm{hr})\end{array}$} \\
\hline Medium & & $\begin{array}{l}\text { In the } \\
\text { presence of } \\
0 \cdot 1 \mu \text { mole of } \\
\text { DL-valine }\end{array}$ & $\begin{array}{c}\text { Inhibition } \\
(\%)\end{array}$ \\
\hline Minimal & 0.54 & $0 \cdot 18$ & 67 \\
\hline $\begin{array}{l}\text { Minimal }+50 \mu \mathrm{g} . / \mathrm{ml} . \mathrm{DL}-\mathrm{valine}+\mathbf{5 0} \mu \mathrm{g} . / \mathrm{ml} \text {. } \\
\text { DL-isoleucine }\end{array}$ & 0.72 & $0 \cdot 20$ & 72 \\
\hline
\end{tabular}


published data of Umbarger \& Brown (1958 $b$ ) that the growth-inhibiting concentration of valine repressed the enzyme formation. The growth-inhibiting and repressive effect was counteracted by the addition of isoleucine and in the presence of both amino acids the enzyme level was about $40 \%$ greater than in the control culture (Table 4). Isoleucine by itself was without effect on enzyme level. The $\alpha$-acetolactic acid-forming enzyme grown under different conditions was sensitive to valine (Table 5).

\section{DISCUSSION}

The first experimental results suggested that in the regulation of the enzymes taking part in the synthesis of valine and isoleucine valine plays a role. Valine, which inhibits the growth of $\mathrm{k} 12$ strain of Escherichia coli (Tatum, 1946; Umbarger \& Brown, 1955), competitively inhibits the $\alpha$-acetolactic acid-forming enzyme (Umbarger \& Brown, 1958b). The enzyme to be found in variants resistant to valine (Leavitt \& Umbarger, 1962) cannot be inhibited by valine. It was shown that valine represses the enzyme level which normally increases during the initial period of growth (Umbarger \& Brown, 1958 b; Halpern \& Umbarger, 1959). Later, experiments carried out by Freundlich et al. (1962), with an auxotroph of Salmonella typhimurium, showed that the formation of the enzymes taking part in the synthesis of valine, isoleucine and leucine can be repressed by the end products.

In this paper the regulation of valine and isoleucine metabolism has been investigated in Pseudomonas aeruginosa and Escherichia coli. It has been observed in the course of experiments that the $\alpha$-acetolactic acid-forming enzyme substantially increases after inoculation, the phenomenon which has already been demonstrated in $\boldsymbol{E}$. coli (Umbarger \& Brown, 1958b), and in Aerobacter aerogenes (Halpern \& Umbarger, 1959). This initial increase can be modified by the addition of the end products to the growth medium. In P. aeruginosa, as in E. coli and A. aerogenes, valine represses this increase in enzyme content of the organisms during the early stages of growth. But, unlike the other two organisms, isoleucine exerts an end-product induction effect which is in evidence during the entire growth period. The endproduct induction was first noted by Gorini (1960), and Gorini \& Gundersen (1961), in connexion with the biosynthesis of arginine. The induction effect can be demonstrated also with isoleucine, produced endogenously, from threonine and $\alpha$-ketobutyric acid, or with exogenous isoleucine, and this is the probable cause of the suitability of $\boldsymbol{P}$. aeruginosa strains for the production of isoleucine (Chibata, Kisumi \& Ashikaga, 1960). The induction effect of isoleucine was decreased by valine. It could be observed that the repressive effect of valine can be counteracted by isoleucine, an effect which has also been noted with $E$. coli.

Experimental findings in this work are supported by the fact that parallelism is found between the change in the concentration of the $\alpha$-acetolactic acid-forming enzyme and that of the $\alpha, \beta$-dihydroxyacid dehydrase.

It was found in experiments carried out here that in the case of both organisms valine and isoleucine have opposing effects in the regulation, though no stoichiometric relationship between the quantity and the effect of amino acids added to the medium could be detected. Cohen \& Rickenberg (1956) observed that the uptake of valine and isoleucine is an active process, and moreover that the uptake of valine can be inhibited by isoleucine. It seems probable that the reason we could not find any 
stoichiometric relationship is due to the fact that permease has an effect on intracellular concentrations of valine and isoleucine. The results obtained by Cohen \& Rickenberg (1956) do not explain our results, because they studied only the active uptake of valine.

It should be emphasized that the effects found are in evidence only in the initial stage of growth when there is a spontaneous increase of the enzyme levels. The changes can be explained on the basis of theories accepted at present (Szilárd, 1960): the concentration of valine and isoleucine inside the cells regulates the enzyme levels which take part in the synthesis of the two branched chain amino acids.

The initial rise of the enzyme levels can be observed also in other strains, e.g. in Mycobacterium pellegrino, M. smegmatis, Streptomyces rimosus and S. fradiae (Horváth et al. unpublished results). It seems probable that this rise is important biologically. Attempts have been made to elucidate this problem in our laboratory.

\section{REFERENCES}

Cavaluini, D. \& Frontali, N. (1954). Quantitative determination of keto-acids by paper chromatography. Biochim. biophys. Acta, 13, 439.

Chibata, J., Kisumi, M. \& Ashikaga, Y. (1960). Studies on the fermentative production of L-isoleucine. J. biochem. microbiol. Technol. Engng, 2, 361.

Cohen, G. N. \& Rickenberg, H. V. (1956). Concentration spécifique réversible des amino acides chez Escherichia coli. Annls. Inst. Pasteur, Paris, 91, 693.

Davis, B. D. \& Mingiou, E. (1950). Mutants of Escherichia coli requiring methionine or vitamin $B_{12}$. J. Bact. 60, 17.

Freundlich, M., Burns, R. O. \& Umbarger, H. E. (1962). Control of isoleucine, valine and leucine biosynthesis. I. Multivalent repression. Proc. nat. Acad. Sci., Wash. 48, 1804.

Gorint, L. (1960). Antagonism between substrate and repressor in controlling the formation of a biosynthetic enzyme. Proc. nat. Acad. Sci., Wash. 46, 682.

Gorini, L. \& GuNDERSEN, W. (1961). Induction by arginine of enzymes of arginine biosynthesis in E. coli B. Proc. nat. Acad. Sci., Wash. 47, 961.

Halpern, Y. S. \& Umbarger, H. E. (1959). Evidence for two distinct enzyme systems forming acetolactate in Aerobacter aerogenes. J. biol. Chem. 234, 3067.

Horváth, I., Gadó, I. \& Szentirmai, A. (1961). Possible causes for production of isoleucine by Streptomyces rimosus. Nature, Lond. 192, 641.

Horvíth, I., Gadó, I. \& Szentirmai, A. (1962). Valine and isoleucine metabolism of Streptomyces rimosus. Acta microbiol. hung. 9, 11.

LeavitT, R. I. \& Umbarger, H. E. (1962). Isoleucine and valine metabolism in E. coli. XI. Valine inhibition of the growth of $E$. coli strain K-12. J. Bact. 83, 624.

Lowry, O. H., Rosebrough, N. I., Farr, A. L. \& Randall, R. J. (1951). Protein measurement with the Folin phenol reagent. J. biol. Chem. 193, 265.

Meister, A. \& TiCe, S. V. (1950). Transamination from glutamine to keto acids. J. biol. Chem. 187, 173.

Radhakrishnan, A. N. \& Snelx, E. E. (1960). Biosynthesis of valine and isoleucine. II. Formation of $\alpha$-acetolactate and $\alpha$-aceto- $\beta$-hydroxybutyrate in Neurospora crassa and E. coli. J. biol. Chem. 235, 2316.

Sjolander, I. R., Folkers, K., Adelberg, E. A. \& TAtum, E. L. (1954). $\alpha, \beta$-dihydroxyisovaleric acid and $\alpha, \beta$-dihydroxy- $\beta$-methyl-valeric acid, precursors of valine and isoleucine. J. Am. chem. Soc. 76, 1085.

Strassmann, M., Shatton, I. B. \& Weinhouse, S. (1960). Conversion of $\alpha$-acetolactic acid to the valine precursor, $\alpha, \beta$-dihydroxy isovaleric acid. J. biol. Chem. 235, 700.

SzILÁRD, L. (1960). The control of the formation of specific protein in bacteria and in animal cells. Proc. nat. Acad. Sci., Wash. 46, 277. 
TATUM, E. L. (1946). Biochemical mutations in bacteria. Cold Spr. Harb. Symp. quant. Biol. 11, 278.

Umbarger, H. E. \& Brown, B. (1955). Isoleucine and valine metabolism in $E$. coli. VI. Antagonism between isoleucine and valine. J. Bact. 73, 105.

Umbarger, H. E. \& Brown, B. (1958a). Isoleucine and valine metabolism in E. coli. VII. A negative feedback mechanism controlling isoleucine biosynthesis. J. biol. Chem. 233, 4115.

Umbarger, H. E. \& Brown, B. (1958b). Isoleucine and valine metabolism in E. coli. VIII. The formation of acetolactate. J. biol. Chem. 233, 1156.

WESTERFELD, W. W. (1945). A colorimetric determination of blood acetoin. J. biol. Chem. $161,485$.

Wixom, R. L., Shatton, I. B. \& Strassmann, M. (1960). Studies on a dehydrase in valine biosynthesis in yeast. J. biol. Chem. 235, 128. 